\title{
MACHINABILITY TESTS USING CERAMIC TOOLS REINFORCED BY NICKEL-COATED GRAPHENE
}

\author{
TESTY SKRAWALNOŚCI NARZĘDZIAMI CERAMICZNYMI \\ Z DODATKIEM GRAFENU POWLEKANEGO NIKLEM
}

\author{
Tomasz CYGAN ${ }^{1}$, Jarosław WOŹNIAK ${ }^{1}$, Marek KOSTECKI ${ }^{1}$, \\ Kazimierz CZECHOWSKI ${ }^{2}$, Norbert GIERUĆ ${ }^{1}$, \\ Lucyna JAWORSKA ${ }^{2}$, Andrzej OLSZYNA ${ }^{1}$
}

\begin{abstract}
The study concerns the influence of nickle-coated graphene ( $\mathrm{GnNi}$ ) addition to alumina matrix and its impact on cutting performance of obtained composites. Nickel-coated graphene was mixed with alumina powder and consolidated using Spark Plasma Sintering (SPS) method. Influence of modified nano-filler and sintering method on cutting performance and physical such a density, hardness and fracture toughness was analyzed. Obtained composites were formed into cutting tool and subjected to machining tests. Cutting tools life and the surface roughness were investigated for 4 different tests. The results were compared with commercial cutting tools showing good cutting performance.
\end{abstract}

Keywords: ceramic cutting tool, graphene, cutting performance, machinability test

Streszczenie: Niniejszy artykuł omawia działanie dodatku grafenu pokrywanego niklem (GnNi) na osnowę tlenku glinu oraz jego wpływ na właściwości skrawne otrzymanych kompozytów. Grafen pokrywany niklem został wymieszany z proszkiem tlenku glinu i skonsolidowany z użyciem metody Spark Plasma Sintering (SPS). Przeanalizowano wpływ zmodyfikowanego nano-wypełniacza oraz metody spiekania na właściwości skrawne oraz takie właściwości fizyczne jak gęstość, twardość oraz odporność na kruche pękanie. Z otrzymanych kompozytów uformowano narzędzia skrawające, które poddano następnie próbom skrawania. Zbadano długość życia ostrza oraz chropowatość powierzchni dla kompozytu z najlepszymi właściwościami mechanicznymi (1\% wag. dodatku GnNi). Wytworzone ostrza skrawające charakteryzowały się właściwościami skrawnymi na tym samym poziomie co ostrza komercyjne.

Słowa kluczowe: narzędzie skrawające ceramiczne, grafen, właściwości skrawne, test skrawalności

\footnotetext{
${ }^{1}$ Warsaw University of Technology, Faculty of Materials Science and Engineering, ul. Wołoska 141, 02-507 Warsaw, Poland

${ }^{2}$ The Institute of Advanced Manufacturing Technology, ul.Wrocławska 37a, 30-011 Krakow, Poland
} 


\section{INTRODUCTION}

Alumina and other structural ceramics are widely used in the materials industry and can be applied in many fields covering bio-sensors, dental implants, transparent conductors or wear resistance parts $[6,7,12]$. Such applications emerge from high hardness, low density, chemical inertness and corrosion resistance [2], but are restricted by their low fracture toughness and fabrication difficulties $[3,8]$. All the above mentioned properties play very important role in fabricating cutting tools and their further improvement is related to overcoming the restrictions of such materials.

Graphene, due to its unique combination of electrical, mechanical and thermal properties $[1,4,5]$ can greatly improve simultaneously properties of obtained composites [9]. Addition of graphene seems like good filler to improve fracture toughness in ceramic composites by addition of second phase [10]. Although there are also several problems with fabricating such composites and we can categorize them as: obtaining good quality graphene, homogenous distribution of graphene in ceramic matrix and degradation of graphene during high temperature sintering. For each one of those issues exist at least few methods and solutions to solve problem.

In this paper commercial graphene flakes were used which provide required good quality. In order to achieve regular dispersion the powder metallurgy was used. Graphene was first ultrasonicated and then mixed with ceramic powder with addition of solvent in ball milling process. It resulted in good dispersion which should increase mechanical properties. Similar influence has the way sample is sintered, in this work Spark Plasma Sintering was used which allows fast process with high heating rate and relatively low temperature. It prevents large degradation of graphene and grain growth of ceramic matrix.

Additionally to above methods and to further improve mechanical properties, the interface between graphene and ceramic was improved by coating graphene with nickel using electroless plating method [11]. Very few papers have been published so far making such experiment and preparing alumina matrix composites with nickel-coated graphene.

\section{EXPERIMENT}

Powder substrates used in this work were commercial $\alpha-\mathrm{Al}_{2} \mathrm{O}_{3}$ powder (Taimei Chemicals CO., LTD.,) with chemical purity of $99.99 \%$ and the average particle size of $135 \mathrm{~nm}$ and commercial Gn powder (Graphene Supermarket) with chemical purity of $99.9 \%$ and the average flakes size of $12 \mathrm{~nm}$.

The first step of technology was to prepare nickel-coated graphene ( $\mathrm{GnNi}$ ) by ultrasonically dispersing graphene in solution of isopropyl alcohol for 30 minutes, presenting into an electroless plating bath (carried at $80^{\circ} \mathrm{C}$ for 3 minutes) and washing in distilled water. Then nickel-coated graphene was mixed with alumina powder and dispersed in solution of isopropyl alcohol for 30 minutes, dried and sieved. Final consolidation of powder mixtures was made carried out using Spark Plasma Sintering (SPS) method, with parameters of the sintering process as follows: heating rate $250^{\circ} \mathrm{C} / \mathrm{min}$, temperature $1450^{\circ} \mathrm{C}$, dwell time $4 \mathrm{~min}$, puls pattern 15:1 ms on: off and vacuum atmosphere. As a result of sintering four composites were obtained, with different weight content: $\mathrm{Al}_{2} \mathrm{O}_{3}-\mathrm{x} \%$ wt. $\mathrm{GnNi}$ (where $\mathrm{x}=0 / 0.5 / 1 / 2$ ). Production scheme of composites are shown as in Figure 1. 


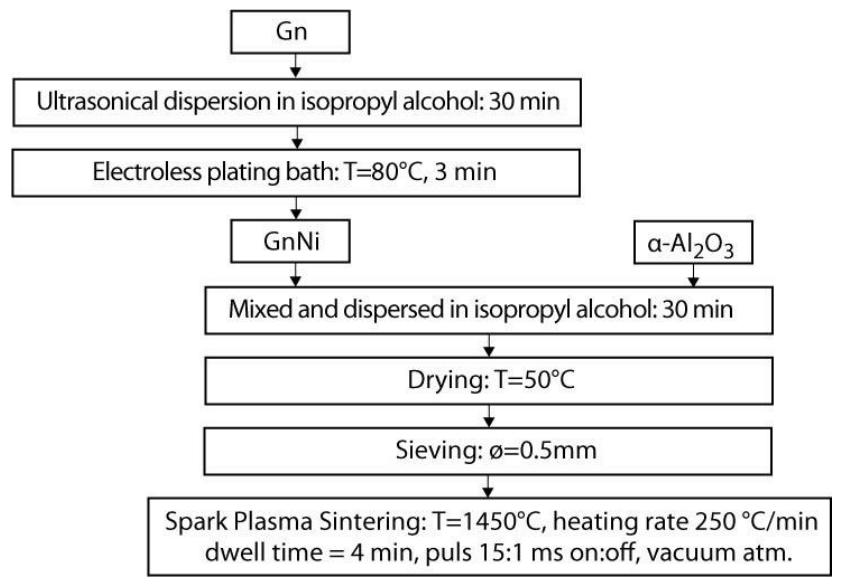

Figure 1. $\mathrm{Al}_{2} \mathrm{O}_{3}-\mathrm{x} \%$ wt. GnNi production scheme

Samples were mechanically grinded and polished to a grit size size of $0.2 \mu \mathrm{m}$. Density of specimens were examined with the use of helium pycnometer (Ultrapycnometer 1000 Quantachrome Instruments), hardness and fracture toughness were measured with a Vickers Hardness Tester (FV-700e Future-Tech) with the use of the indentation method under the load of $49.03 \mathrm{~N}$.

For machining tests composite with addition of $1 \%$ weight content of nickel-coated graphene was selected as one with best properties such as hardness and fracture toughness. Square crosssection cutting tool was manufactured according to ISO 1832:1991 in type of SNGN 120412 T02020 and tested using CNC machine type NL2000SY (Mori Seiki) with machined material of hardened tool steel $145 \mathrm{Cr} 6$ (hardness $50 \pm 2 \mathrm{HRC}$ ). Four different tests were carried out with following parameters: cutting speed $v_{c}-370 \mathrm{~m} / \mathrm{min}$, cutting feed $f-0.08 \mathrm{~mm} / \mathrm{rot}$, depth of cut $a_{p}-0.3 \mathrm{~mm}$. Each of test was executed using dry machining.

Cutting performance was determined with survey of the tool wear defined by a flank wear indicator (width) $V B_{C}=0.3 \mathrm{~mm}$ (according to PN-ISO 3685:1996) and surface roughness parameter $R a$ which was measured with profilometer (Hommel Tester T1000E). Obtained results of the machining tests were compared with those of commercial ceramic cutting tool in type of $\mathrm{Al}_{2} \mathrm{O}_{3}+\mathrm{ZrO}_{2}+\mathrm{Ti}(\mathrm{C}, \mathrm{N})$.

\section{RESULTS AND DISCUSSION}

Measurement of relative density shows its high value (higher than 96\%) for all four samples as shown in Figure 2, although densities of composites were noticeable lower than density of pure alumina. Tendency shows that density value decreases with increasing weight content of nickel-coated graphene, which can happen due to increase of volume fraction of agglomerates of GnNi particles. 


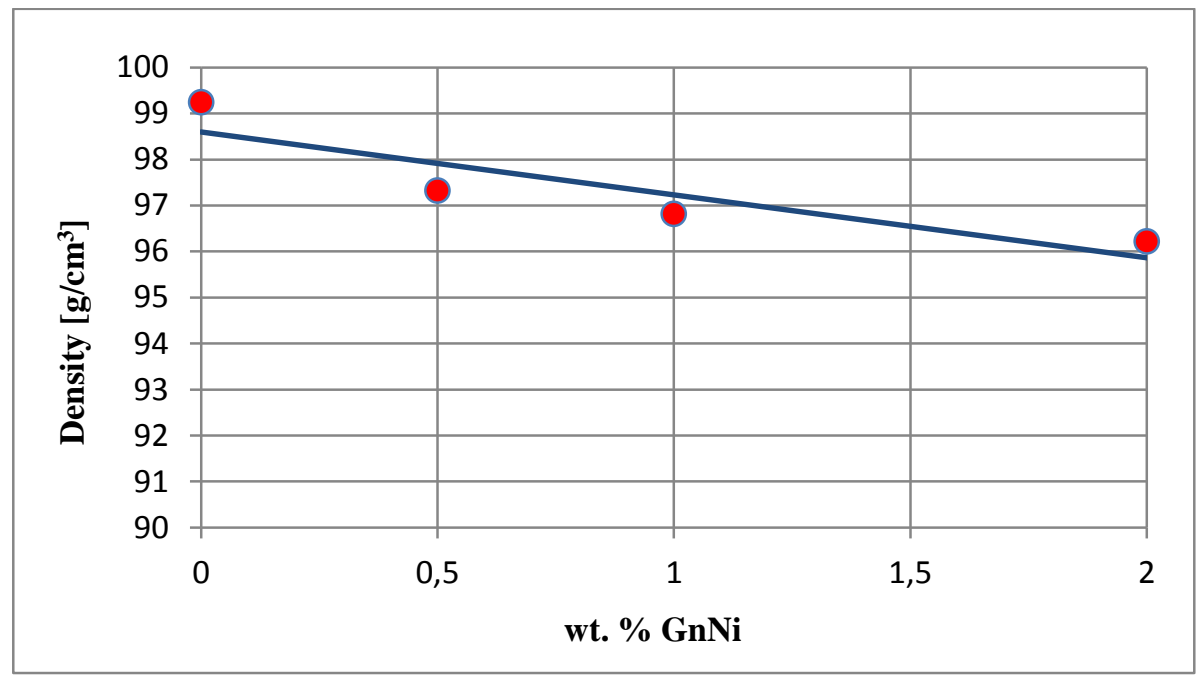

Figure 2. Influence of nickel-coated graphene weight content on relative density of obtained composites

Vickers hardness for all obtained composites is in similar range and equals $1550 \pm 25 \mathrm{HV} 5$. As shown in Figure 3 this result is only slightly lower than for reference sample without addition of second phase.

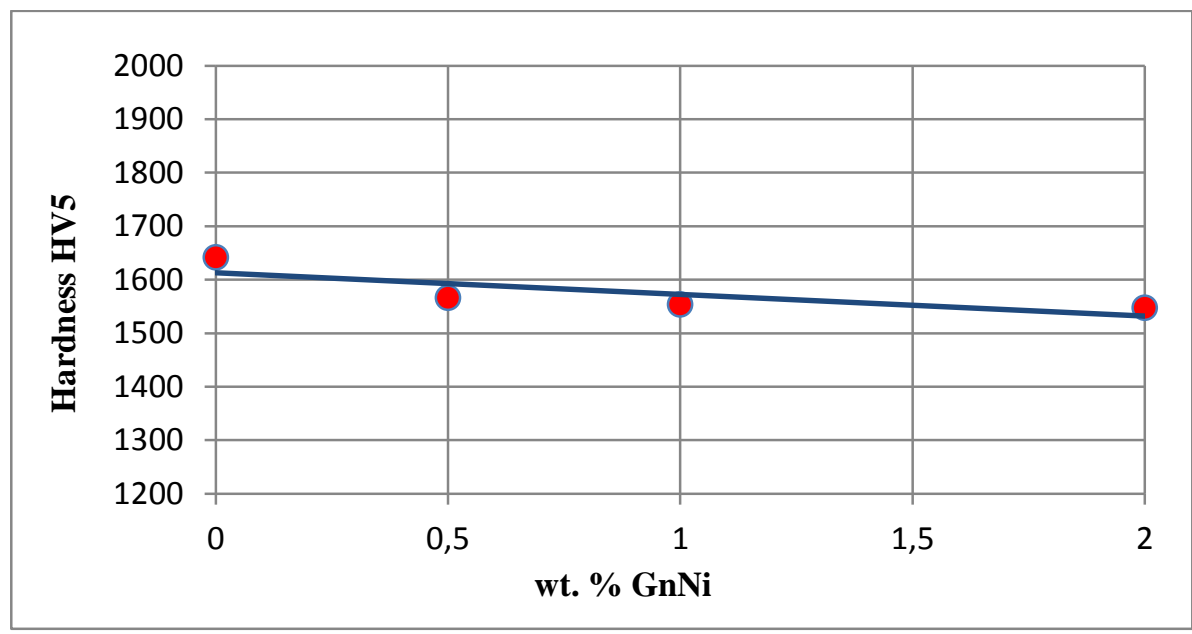

Figure 3. Influence of nickel-coated graphene weight content on hardness of obtained composites

Results for fracture tougness measurements as shown in Figure 4 are very similar to this reported by other researchers in their works [8]. We can observe increase of $\mathrm{K}_{\mathrm{IC}}$ coefficient for composite with 1 wt.\% of nickel-coated graphene where it reached $\mathrm{K}_{\mathrm{IC}}=3.78 \mathrm{MPa}^{*} \mathrm{~m}^{0.5}$ and further decrease of fracture tougness for composites with higher addition of $\mathrm{GnNi}$. 


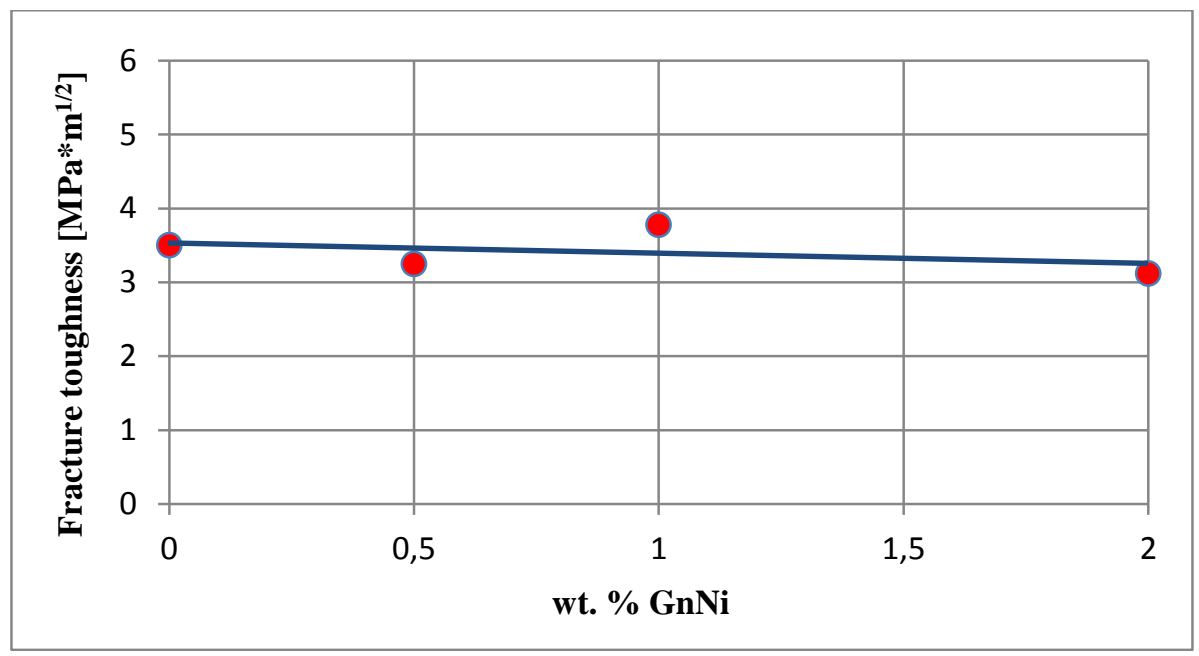

Figure 4. Influence of nickel-coated graphene weight content on fracture toughness of obtained composites

Four machining tests were performed for composite with $1 \mathrm{wt} . \%$ addition of nickel-coated graphene to alumina matrix. Obtained results for cutting tool life are as shown in Figure 5. The average tool life reached $7.3 \mathrm{~min}$ with standard deviation of $1.0 \mathrm{~min}$. This results are lower to those measured for commercial sample $(9.8 \pm 0.5 \mathrm{~min})$, but taking into account high cutting speed $V_{c}-370 \mathrm{~m} / \mathrm{min}$ we can state, that tool prepared from alumina - nickel-coated graphene showed similar cutting performance.

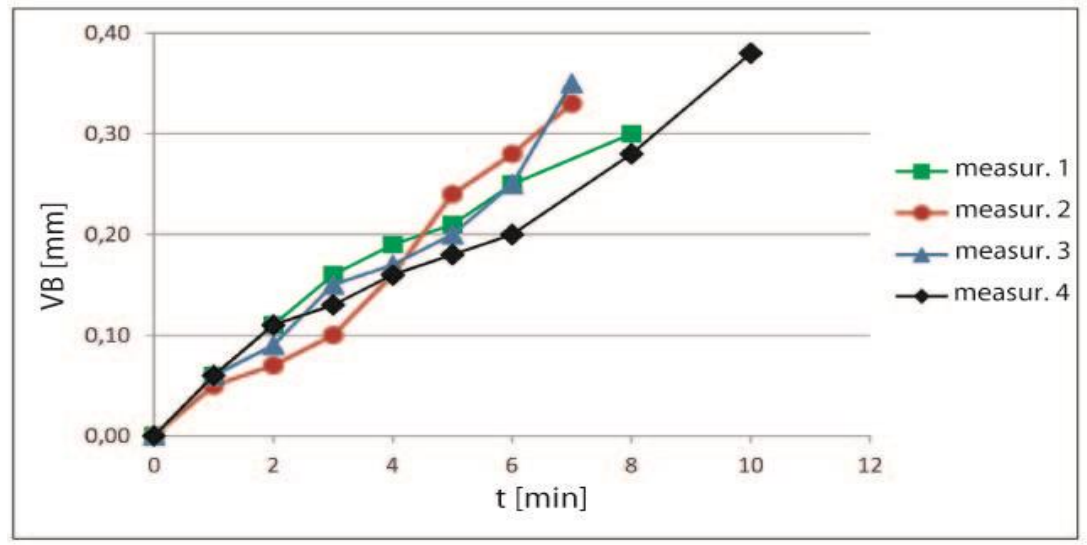

Figure 5. Wear tests results for $\mathrm{Al}_{2} \mathrm{O}_{3}-1 \%$ wt. GnNi composite tool

Similar comparison was reached for the surface roughness parameter $R a$ between commercial and tested cutting tools. As shown in Figure 6 for composite with 1 wt.\% addition of $\mathrm{GnNi}$, values of surface roughness was in range from 0.15 to 0.5 . For commercial cutting tool results 
in range from 0.2 to 0.6 were reached, which overlap with results for tested composite. We can conclude that surface roughness parameter $R a$ is in range of finishing cutting $(0.2-0.7)$.

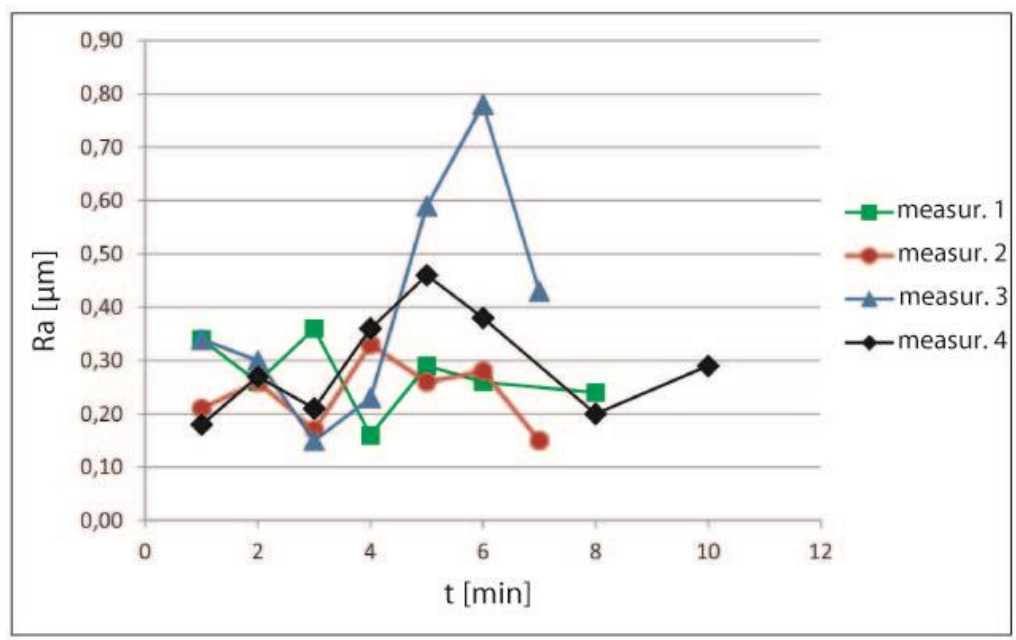

Figure 6. Surface roughness of $145 \mathrm{Cr} 6$ steel results after machining with $\mathrm{Al}_{2} \mathrm{O}_{3}-1 \%$ wt. GnNi composite tool

\section{CONCLUSIONS}

Nickel-coated grahpene as reinforcement in alumina matrix composites can be efficiently applied. Since not much research was done on this subject so far, there are still few aspects which requires improvement. More work should be done to obtain composites with higher homogeneity, which will result in fabricating samples with even better mechanical properties and higher density. That can be achieved by optimizing electroless plating process. Spark Plasma Sintering process seems good method for sintering powders where no degradation to graphene is required. Presented method of sintering and addition of $\mathrm{GnNi}$ as second phase into alumina matrix composites influence positively such parameter as fracture toughness which is highly required for presented applications. Moreover machining tests of produced composite with $1 \mathrm{wt}$ \% addition of filler shows similar results of cutting tool life and surface roughness as those using commercial alumina based ceramic tools. Further improving preparation of composite can result reaching better mechanical parameters for obtained composites, comparable with commercial.

\section{ACKNOWLEDGEMENTS}

Financial support from the Polish Ministry of Science and Higher Education (Grant No. 513R/1090/0740/000 “GRAF-TECH”) is gratefully acknowledged. 


\section{REFERENCES}

[1] BALANDIN A.A., GHOSH S. BAO W.Z., CALIZO I., TEWELDEBRHAN D., MIAO F. et al. Superior thermal conductivity of single-layer graphene, Nano Lett. 2008;8(3), 902-907.

[2] BRONISZEWSKI K., WOŹNIAK J., CZECHOWSKI K., JAWORSKA L., OLSZYNA A., $\mathrm{Al}_{2} \mathrm{O}_{3}$ - $\mathrm{Mo}_{\mathrm{cutting}}$ tools for machining hardened stainless steel, Wear 303 (2013), 87-91.

[3] BRONISZEWSKI K., WOŹNIAK J., KOSTECKI M., OLSZYNA A., Properties of alumina - graphene oxide composites, Materials Today Proceedings, in press.

[4] GEIM A.K., NOVOSELOV K.S., The rise of graphene, Nat Mater 2007;6(3), 183-191.

[5] LEE C., WEI X.D., KYSAR J.W., HONE J., Measurement of the elastic properties and intrinsic strength of monolayer graphene, Science 2008;321(5887), 385-388.

[6] LIU J., YAN H., JIANG K., Mechanical properties of graphene platelet-reinforced alumina ceramic composites, Ceramics International 39 (2013), 6215-6221.

[7] MOHANTY N., BERRY V., Graphene-based single-bacterium resolution biodevice and DNA transistor: interfacing graphene derivatives with nanoscale and microscale biocomponents, Nano Lett. 2008; 8(12), 44694476.

[8] PORWAL H., TATARKO P., GRASSO S., KHALIQ J., DLOUCHY I., REECE M.J., Graphene reinforced alumina nano-composites, Carbon 64 (2013), 359-369.

[9] WALKER L.S., MAROTTO V.R., RAFIEE M.A., KORATKAR N., CORRAL E.L., Toughening in graphene ceramic composites, ACS Nano 2011:5(4), 3182-3190.

[10] WANG K., WANG Y.F., FAN Z.J., YAN J., WEI T., Preparation of graphene nanosheet/alumina composites by spark plasma sintering, Mater Res Bull 46 (2) (2011), 315-318.

[11] WOŹNIAK J., KURTYCZ P., BRONISZEWSKI K., KOSTECKI M., MORGIEL J., OLSZYNA A., Properties of alumina matrix composites reinforced with nickel-coated graphene, Materials Today Proceedings, in press.

[12] WU J.B., AGRAWAL M., BECERRIL H.A., BAO Z.N., LIU Z.F., CHEN Y.S., et al. Organic light-emitting diodes on solution-processed graphene transparent electrodes, ACS Nano 2010; 4(1), 38-43. 